E3 Journal of Business Management and Economics Vol. 8(1). pp. 038-046 April, 2017

Available online http://www.e3journals.org

ISSN 2141-7482 @ E3 Journals 2017

DOI : http://dx.doi.org/10.18685/EJBME(8)1 EJBME-17-010

\title{
Promoting entrepreneurship for poverty reduction and sustainable development in Nigeria
}

\author{
Eneji Mathias Agri ${ }^{1,2^{\star}}$, Dalut Alfred Nanwul ${ }^{1}$ and Odey Francis Acha ${ }^{3}$ \\ ${ }^{1}$ Department of Economics, University of Jos, Nigeria \\ ${ }^{2}$ China-Africa Science and Technology Foundation, Beijing \\ ${ }^{3}$ Nigeria, Ministry of Foreign Affairs, Abuja
}

Accepted 6 March, 2017

\begin{abstract}
Economic development can be realized with the elimination of mass poverty and unemployment. The objective of this study is to evaluate entrepreneurship for poverty reduction and sustainable development in Nigeria. This study uses representative sample survey of private enterprises in North-Central Nigeria to investigate the opportunities, constraints and overall impact of entrepreneurship on poverty reduction and sustainable development. SMEs in hair dressing and beauty salon, foods, bottle water, farm fresh products, wholesale and retail trade were investigated. The survey also exposes the factors responsible for failures in policies and programs intended to benefit the poor and generally reduce poverty. This research finds that small scale entrepreneurs in Nigeria face many constraints and it underscored the need for fiscal priority to be placed on skills acquisition, rural development, agriculture, animal husbandry, community participation, forestry, community health, irrigation, rural education, infrastructure, land development and small scale business empowerment in rural areas. Nigerian graduates deserve employability, career development training and skills acquisition. Nigeria needs to take advantage of her primary product endowment to manufacture, invent and invest heavily in infrastructure and industrial development. We conclude that Nigeria has a large economy and it is wealthendowed for entrepreneurship.
\end{abstract}

Keywords: Entrepreneurship, Innovation, Poverty Reduction, Sustainable Development, Nigeria.

\section{INTRODUCTION}

During the 1980s, entrepreneurship education attracted mainstream scholars in Nigeria. New programs of entrepreneurship have begun to flourish, led by the Lagos Business School, (Eneji, 2014). Others such as the Jos Business School and the Niigerian Universities Commission (NUC) are doing the same. This is in line with what is obtainable in Harvard Business School, London school of Economics, Management Institute of Technology (MIT), Stanford, the Wharton School, China University of Business and Economics, and UC Berkeley etc. America for instance became a world economic power through entrepreneurship. In the neoclassical production theory, entrepreneurship is a factor of

\footnotetext{
*Corresponding author email: agrieneji@yahoo.com
}

production separate from land, labor and capital. An entrepreneur is a person who combines the other factors of production, takes the risk of setting up his or her own business venture for perceived rewards - profits. Entrepreneurs distinguish themselves in business by creating something new, something different, they change or transmute values. Schumpeter (1934) describes entrepreneurship as a process, and the entrepreneur as innovator who use the process to shatter the status quo through new combinations of resources and new methods of commerce. Entrepreneurs add value to the economy through taking risks and rewards associated with the process, (Bell and Pavitt, 1993; Ndebbio, 1994). They reform the patterns of production by exploiting an invention or, more generally, an untried technological possibility for producing, a new commodity or producing an old one in a new way. 
The entrepreneurial role is that of gathering resources;organize talent, and providing leadership to make it a commercial success. Adam Smith refers to the entrepreneur as the "Enterpriser" in his "Wealth of Nations" (1776). The enterpriser is an individual who undertook the formation of an enterprise for commercial purposes. Smith thereby ascribed to the entrepreneur the role of industrialist. Ronstadt (1984) defines entrepreneurship as a dynamic process of creating incremental wealth. This wealth is created by individuals who assume the major risks in terms of equity, time and/or career commitment of providing value for some product or service. We accept these concepts, however, strictly in context; we refer to the entrepreneur as an economic agent who transforms demand into supply, increase productivity, create jobs and contribute to sustainable development in Nigeria, example, Aliku Dangote. In the structure of this paper, statement of research problem follows the introduction as part 2 . In part three, we state our objectives, while literature review is in part 4. Others are methods and results in part 5, discussion of findings in part 6 , recommendations and conclusion are in part 7 and 8 respectively.

\section{Statement of research problem}

Poverty and unemployment of young people have become increasingly critical problems in Nigeria. Between 1962 and 1985, the Nigeria government implemented four national development plans and a national rolling plan as part of a perspective plan, Mailafia, (2016). All these were designed to achieve some specific development objectives; increase the real income of the average citizen, as well as a more even distribution of income; a reduction in the level of unemployment and underemployment; increased sectoral and regional balanced development; increased participation of Nigerians in the ownership and management of productive enterprises; increased dependence on local resources in the development process and maintenance of economic stability. In spite of these efforts, Nigeria is still bedeviled by mass poverty and high income concentration among small group of politicians, oil businessmen, and importers. High unemployment amongst young graduates; underemployment, lack of manufacturing capacity, overdependence on petroleum and excessive imports of goods and services have become thorny issues. Due to over-dependence on crude oil, the once booming agricultural industry in the 1960 s, declined to a state where Nigeria is now forced to import basic foods like rice, wheat, tomato, fruits, cooking oil and even vegetables, (Eneji,2014). These further led to the reaction of policy makers in formulating the National Economic Empowerment and Development Strategy (NEEDS), Statement Economic Empowerment and Development
Strategy (SEEDS), and Local Economic Empowerment and Development Strategy (LEEDS).

There is need to microfinance SMEs in these essential areas for self-reliance growth and sustainable development.

It is an irony that Nigerian universities and polytechnics have many smart, talented and ambitious students that need to be equipped with the kind of skills that permit them to enter the local and international labor market with confidence and find suitable jobs. They are smart and talented enough to produce made-in-Nigeria smart phones, cars and laptops through learning-by-doing. However, these students swam the labor market without jobs.

Stagnation in entrepreneurship, unemployment and increasing level of poverty inform this research. Others are imported inflation, social and economic inequality, political corruption, environmental problems, macroeconomics and political instability which work against sustainable development. There is need to shift from the position of total dependence to semi-detachment through import-substitution, entrepreneurship and industry. Nigeria should learn lessons from the global oilshock and global financial crisis. Other reasons in support of entrepreneurship and self-reliance economic development include occasions of war; trade war or real war. In the case of eventuality, like the 1st and 2nd World Wars, Nigeria needs to be proactive, to build a resilient and self-reliance nation.

\section{Objective of study}

The objective of study is to evaluate entrepreneurship for poverty reduction and sustainable development in Nigeria. Nigerian graduates deserve employability, career development training and skills acquisition. Nigeria needs to take advantage of her primary product endowment to manufacture, invent and invest heavily in infrastructure and industrial development. Nigeria should ban the importation of goods and services that can be produced at home in order to create jobs as well as increase government revenue for sustainable development. The objective of this study is to attempt answering two basic questions: (i) How bad, are the poverty and unemployment levels and how has entrepreneurship intervention helped?

Why have there been failures in policies and programs intended to benefit the poor and generally reduce poverty?

\section{LITERATURE REVIEW}

Historically, Portuguese navigational instruments opened the world to rapid colonization. Scottish descent in Britain's steam engine and power looms brought about 
industrial revolution in Europe. Pickle and Soa (1976) maintained that small enterprises do not only help to industrialize the American economy, but that they are also instruments of employment generation. American technology in aviation and auto industry, computer and information technology has changed production and productivity world over. Innovations in microelectronics have thrust the world into the post-industrial information age. The Chinese invented gun powder and paper printing, and are their own architects of rapid poverty reduction in China through rural agricultural transformation and manufacturing, (Gao and Zhuang, 2011). The theorists of mercantilism argued that economic activity is centered on trade and exchange. It was the theory of the early commercial bourgeoisie. The conclusion which was drawn from this view of the nature of economic activity was that the government should be strong enough to break down feudal patterns of restriction of trade, and that thereafter, the government should exercise regulation of internal trade via guilds and monopolies in order to avoid damaging competition, (Malton,1978). In respect of external trade, mercantilists took the view that the state should assist them as much as possible in competition with the merchants of other countries as the role of external trade was primarily to accumulate wealth in the form of precious metals. In the early years of the expansion of the European powers, major trading companies were established. They were powerful and influential at home and acted as surrogate governments in the slowly accumulated overseas possessions. As mercantile theory found expression in practice in the early years of the expansion of European mercantile capitalism, there were conflicts between trading nations which looked to protect exclusive spheres of activities. It is mercantilism that matured into globalization. In the internal structure, the system slowly became untenable as resentments of the peasants began to coincide with the irritations of the emergent commercial bourgeoisie. A respite was sought in the theory of economics proposed by the physiocrates about economic activity centered on the production of goods and in turn derived from a strong agriculture. It is on the basis of this early movement towards liberal trade capitalism that the slow shift to the full-fledged industrial capitalism of the 19th century began. As the economic activities of the merchants and manufacturers develop, so too does their political power and as they begin to move towards the center of the social and political sphere, this in turn demands new social theory to articulate their interests. It is on the basis of commercial liberal capitalism that industrial capitalism subsequently develops. Adam Smith articulates this new commercial liberal capitalist interest, show how the free pursuit of private gain can act to raise the standard of living of the entire community (state). In the work on ethics, Adam Smith shows how self-interest can be linked to an appreciation of the role of the community in supporting and disciplining individual activities. In "The Wealth of Nations",(1776),individual economic activities can be pursued within the community to the mutual benefit of both individual and community. In Smith's analysis, wealth was derived from creative human labour working on available natural resources in order to produce useful objects. There is no nation that can be wealthy and self-reliant without developing and utilizing indigenous talents and technologies,(Karibu and Dairo,2000; Mafuyal, 2013). Entrepreneurship therefore is the art or science of finding profitable solutions to societal problems, example Bill Gate's Microsoft, Apple in the USA, and Innoson Motors Nigeria Limited or Lenovo in China. Schumpeter, in the 20th century, recognized creative destruction in the process of entrepreneurship development,(Carree and Thurik,2003). Development economics views entrepreneurship as the driving force in the transformation of the structure of an economy. (Gries and Naude',2008; Thompson,2005; Naude',2010). The OECD considers entrepreneurship as the combination of entrepreneurial activities, which are determined by entrepreneurs or innovators, (Ahmad and Hoffman, 2008). Entrepreneurship is directly linked with a valuecreation process or higher productivity, (Kirzner,1998; Lu,1994; Sobel,2008). Ahmad and Hoffman, (2008) identified six determinants of entrepreneurship development: government policy, finance, market, technology, competition and entrepreneurial capability. Significant policy measures that facilitated entrepreneurship development in China in the 1990s include exchange rate control, removal of entry barriers to exports, expanded tariff, removal of trade barriers, import substitution and export promotion, (Naughton,2007). China's joining of WTO in 2001, was also a boost to entrepreneurship. Empirically, Seyfi et al. (2012), studied and measured entrepreneurship intentions of pupils who are registered in different programs of vocational high school in Europe. These intentions were benchmarked with theoric hypotheses, and with attractive results. Cemal et al. (2012) studied the impact of corporate entrepreneurship on organizational citizenship. They used a sample survey of 375 small to medium sized enterprises in the manufacturing sector with Chi-square statistical analysis. Similarly, Daniela and Angela,(2012) investigated entrepreneurship and sustainable development in Europe before and during the international crisis. Data were collected from Eurostat and Global Entrepreneurship Monitor data bases. In order to obtain new variables regarding the correlations between entrepreneurship and sustainable development, they applied Principal Components Analysis (PCA), using Statistical Packages for Social Sciences (SPSS) software package. Nihan and Olcay,(2012) conducted an empirical evaluation of entrepreneurship intentions of public universities in Turkey. They used Qualitative Content Analysis(QCA). Their findings show that entrepreneurial intentions of universities are reflected in their culture, 
strategies, institutional infrastructure and collaborations/partnerships.

\section{METHODS AND RESULTS}

This study uses representative sample survey of private enterprises in North-Central Nigeria to investigate the opportunities, constraints and overall impact of entrepreneurship on poverty reduction and sustainable development. SMEs in Plateau covering food and agriculture, hair dressing beauty salon, bottle water, fresh farm produce, wholesale and retailing were contacted. The survey also exposes the factors responsible for failures in policies and programs intended to benefit the poor and generally reduce poverty. The simple percentages statistical technique is used for data analysis,( Eneji,2015). Results are presented in the following table 1 and 2 .

The statistical evaluation in the table was done from the collation of field questionnaires and survey. For each question on environmental and business constraints to entrepreneurship evaluated, for example, the first question in the table is whether electricity supply is a critical factor/constraint of entrepreneurship in Nigeria, . This evaluation is conducted thus: $(53.1 / 100 \times 5+-----$ $10.1 / 100 \times 2)=4.044$

Evaluation and data analysis from table 1.

$\mathrm{EVA}=2.655+0.82+0.306+0.202+0.061=4.044$

$53.1 / 100 \times 5+20.5 / 100 \times 4+10.2 / 100 \times 3+10.1 / 100 \times$ $2+6.1 / 100$

$2.655+0.82+0.306+0.202+0.061=$ 4.044

$52.3 / 100 \times 5+15.6 / 100 \times 4+12.8 / 100 \times 3+10.3 / 100 \times$ $2+9 / 100$

$2.615+0.624+0.384+0.206+0.09=$ 3.919

$30.5 / 100 \times 5+20.3 / 100 \times 4+10.2 / 100 \times 3+20.6 / 100 \times$ $2+18.4 / 100 \times 1$

$1.525+0.812+0.306+0.412+$ $0.184=3.239$

$40.4 / 100 \times 5+15.5 / 100 \times 4+20.4 / 100 \times 3+15.5 / 100 \times$ $2+8.2 / 100 \times 1$

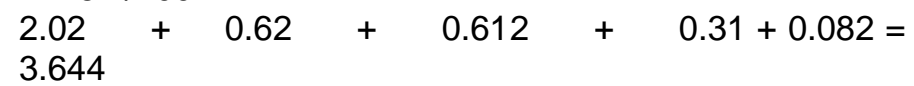

$45.2 / 100 \times 5+30.1 / 100 \times 4+12.4 / 100 \times 3+8.2 / 100 \times$ $2+4.1 / 100 \times 1$

$2.26+1.204+0.372+0.164+0.041=$ 4.041

$20.6 / 100 \times 5+30.4 / 100 \times 4+25.6 / 100 \times 3+12.8 / 100 \times$ $2+10.6 / 100 \times 1$
$1.03+106=3.376$
0.106

$15.3 / 100 \times 5+26.1 / 100 \times 4+30.2 / 100 \times 3+21.3 / 100 \times$ $2+7.1 / 100 \times 1$

$0.765+1.044+0.906+0.426+0.071$

$=3.212$

Note: there is no clear distinction between environmental constraints and business constraints contained in tables 1 and 2. The classification is basically for easy analysis. This is because environment is directly linked to business; thus, we can speak about business environment which is fundamental to entrepreneurship and sustainable development.

Thus, statistical parametric tests involving the mean, variance and standard deviation are used to test the hypothesis at $5 \%$ level of significance. This was done to reveal the average differences in the mean and the dispersion of responses. One pair of hypothesis for this study is stated thus:

$\mathrm{HO}$ : Entrepreneurship in Nigeria is independent of the aforementioned constraints.

$\mathrm{H} 1$ : Entrepreneurship in Nigeria is not independent (not free) of the aforementioned constraints.

In table 3 , the observations represent each sample or structured question about the constraints, while the variables represent the scores or responses: $M I R=X 5$, $\mathrm{SIR}=\mathrm{X} 4, \mathrm{VIR}=\mathrm{X} 3, \mathrm{IR}=\mathrm{X} 2$ and $\mathrm{RR}=\mathrm{X} 1$. In the test, the larger the mean, the more reliable the results and vice versa; and the smaller the variance and standard deviation, the more statistically significant is the result. The observation or sample size $(n=12)$ informed the use of student t-statistic to test the hypothesis at the $5 \%$ level of significance. The observed t-value $=1.68<$ the critical tvalue $=2.201$ (two-tailed). This result confirmed that the $\mathrm{HO}$ is statistically insignificant, hence the decision rule is that we reject $\mathrm{HO}$ and accept $\mathrm{H} 1$ : meaning that entrepreneurship in Nigeria is not independent or free from the aforementioned constraints. Otherwise, the constraints are real in the Nigerian business environment. Entrepreneurship can be promoted by minimizing the constraints.

\section{Discussion of findings}

There is a direct link between the private sector, growth of Small and Medium Scale enterprises (SMEs) and the development of entrepreneurship. The private sector has become the central focus for economic development in the world. Within the context of the private sector is the recognition of Small and Medium Scale Enterprises, (Lv and Cai, 2005; Aremu and Adeyemi, 2011). The SMEs have emerged as an important agent of economic and social transformation in all countries of the world, (Onugu, 2005). However, poverty, especially in the rural areas in 
Table 1. Environmental Constraints to Entrepreneurship in Nigeria

\begin{tabular}{|c|c|c|c|c|c|c|}
\hline Constraints/Ratings & 5 & 4 & 3 & 2 & 1 & Eva \\
\hline Electricity & $53.1 \%$ & $20.5 \%$ & $10.2 \%$ & $10.1 \%$ & $6.1 \%$ & 4.044 \\
\hline Fragile infrastructure & $52.3 \%$ & $15.6 \%$ & $12.8 \%$ & $10.3 \%$ & $9 \%$ & 3.919 \\
\hline Official corruption & $30.5 \%$ & $20.3 \%$ & $10.2 \%$ & $20.6 \%$ & $18.4 \%$ & 3.329 \\
\hline $\begin{array}{l}\text { Low agric. } \\
\text { Product/marketing }\end{array}$ & $40.4 \%$ & $15.5 \%$ & $20.4 \%$ & $15.5 \%$ & $8.2 \%$ & 3.644 \\
\hline $\begin{array}{l}\text { Lack of linkages } \\
\text { between industry and } \\
\text { agric. }\end{array}$ & $45.2 \%$ & $30.1 \%$ & $12.4 \%$ & $8.2 \%$ & $4.1 \%$ & 4.041 \\
\hline $\begin{array}{l}\text { Illiteracy and } \\
\text { deficiency in } \\
\text { entrepreneurship } \\
\text { education }\end{array}$ & $20.6 \%$ & $30.4 \%$ & $25.6 \%$ & $12.8 \%$ & $10.6 \%$ & 3.376 \\
\hline $\begin{array}{l}\text { Deficient SMEs } \\
\text { Support and service } \\
\text { system }\end{array}$ & $15.3 \%$ & $26.1 \%$ & $30.2 \%$ & $21.3 \%$ & $7.1 \%$ & 3.212 \\
\hline Political instability & $21.5 \%$ & $20.3 \%$ & $10.9 \%$ & $13.8 \%$ & $33.5 \%$ & 2.825 \\
\hline Policy inconsistency & $30.4 \%$ & $40.3 \%$ & $12.1 \%$ & $10.2 \%$ & $7 \%$ & 3.769 \\
\hline $\begin{array}{l}\text { Overdependence on } \\
\text { oil sector }\end{array}$ & $40.3 \%$ & $20.5 \%$ & $10.3 \%$ & $18.5 \%$ & $10.4 \%$ & 3.618 \\
\hline $\begin{array}{l}\text { Religious intolerance } \\
\text { and social instability }\end{array}$ & $30.5 \%$ & $12.2 \%$ & $20.1 \%$ & $22 \%$ & $15.2 \%$ & 3.208 \\
\hline Gender discrimination & $20.2 \%$ & $18.8 \%$ & $12.6 \%$ & $10.3 \%$ & $38.1 \%$ & 2.727 \\
\hline
\end{tabular}

Source: Field Survey, 2015; 5= most important reason, 4= Seriously important reason and $1=$ remote reason Eva=Evaluation; 5 = MIR; 4 = SIR; 3 = VIR; 2 = IR; 1 = RR

Table 2. Business Constraints to Entrepreneurship in Nigeria

\begin{tabular}{|c|c|c|c|c|c|c|}
\hline Constraints/Ratings & 5 & 4 & 3 & 2 & 1 & Eva \\
\hline Access to Finance & $58.3 \%$ & $15.5 \%$ & $10.2 \%$ & $10.2 \%$ & $5.8 \%$ & 4.044 \\
\hline Transportation & $50.2 \%$ & $19.6 \%$ & $10.8 \%$ & $10.4 \%$ & $10 \%$ & 2.919 \\
\hline Access to Land & $40.5 \%$ & $20.2 \%$ & $10.3 \%$ & $15.6 \%$ & $13.4 \%$ & 3.329 \\
\hline Government Support & $55.6 \%$ & $17.5 \%$ & $10.4 \%$ & $10.3 \%$ & $6.2 \%$ & 3.644 \\
\hline Tax Rates & $48.2 \%$ & $30.5 \%$ & $9.2 \%$ & $8.00 \%$ & $4.1 \%$ & 4.041 \\
\hline $\begin{array}{l}\text { Customs and Trade } \\
\text { Regulations }\end{array}$ & $40.6 \%$ & $20.4 \%$ & $15.6 \%$ & $12.8 \%$ & $10.6 \%$ & 3.376 \\
\hline $\begin{array}{l}\text { Practices of Informal } \\
\text { Sector }\end{array}$ & $25.5 \%$ & $26.1 \%$ & $20.2 \%$ & $21.1 \%$ & $7.1 \%$ & 3.212 \\
\hline $\begin{array}{l}\text { Macroeconomic } \\
\text { instability }\end{array}$ & $30.6 \%$ & $20.3 \%$ & $10.9 \%$ & $13.8 \%$ & $24.4 \%$ & 2.825 \\
\hline ICT Challenges & $32.5 \%$ & $38.2 \%$ & $10.1 \%$ & $1 \mathrm{v} 2.2 \%$ & $7 \%$ & 3.769 \\
\hline $\begin{array}{l}\text { Lack of Technology } \\
\text { Innovation }\end{array}$ & $45.2 \%$ & $20.6 \%$ & $10.3 \%$ & $13.4 \%$ & $10.5 \%$ & 3.618 \\
\hline $\begin{array}{l}\text { Lack of adequate } \\
\text { Entrepreneurial Skills }\end{array}$ & $40.4 \%$ & $12.3 \%$ & $21.1 \%$ & $12 \%$ & $14.2 \%$ & 3.208 \\
\hline $\begin{array}{l}\text { Lack of infant industry } \\
\text { protection }\end{array}$ & $35.2 \%$ & $18.3 \%$ & $13.5 \%$ & $10.4 \%$ & $22.6 \%$ & 2.727 \\
\hline
\end{tabular}


Table 3. represents the observations and variables in a parametric test analysis

\begin{tabular}{lccccc}
\hline $\begin{array}{l}\text { Observation/ } \\
\text { Variables }\end{array}$ & $\mathbf{X 5}$ & $\mathbf{X 4}$ & $\mathbf{X 3}$ & $\mathbf{X 2}$ & $\mathbf{X 1}$ \\
\hline $\mathbf{1}$ & 53.1 & 20.5 & 10.2 & 10.1 & 6.1 \\
$\mathbf{2}$ & 52.3 & 15.6 & 12.8 & 10.3 & 9 \\
$\mathbf{3}$ & 30.5 & 20.3 & 10.2 & 20.6 & 18.4 \\
$\mathbf{4}$ & 40.4 & 15.5 & 20.4 & 15.5 & 8.2 \\
$\mathbf{5}$ & 45.2 & 30.1 & 12.4 & 8.2 & 4.1 \\
$\mathbf{6}$ & 20.6 & 30.4 & 25.6 & 12.8 & 10.6 \\
$\mathbf{7}$ & 15.3 & 26.1 & 30.2 & 21.3 & 7.1 \\
$\mathbf{8}$ & 21.5 & 20.3 & 10.9 & 13.8 & 33.5 \\
$\mathbf{9}$ & 30.4 & 40.3 & 12.1 & 10.2 & 7 \\
$\mathbf{1 0}$ & 40.3 & 20.5 & 10.3 & 18.5 & 10.4 \\
$\mathbf{1 1}$ & 30.5 & 12.2 & 20.1 & 22 & 15.2 \\
$\mathbf{1 2}$ & 20.2 & 18.8 & 12.6 & 10.3 & 38.1 \\
$\overline{\mathbf{X}}$ & 33.4 & 22.55 & 15.65 & 14.47 & 13.98 \\
$\mathbf{S}$ & 165 & 62.18 & 45.85 & 25 & 1322 \\
$\mathbf{S}$ & 12.85 & 7.89 & 6.77 & 5 & 36.4 \\
\hline
\end{tabular}

Source: Computed from field survey data

Nigeria, is like a web in which the lack of capital, inadequate stocks and flows of food and income, physical weakness and sickness, isolation, vulnerability and powerlessness form an interlock against the helpless poor. These work against entrepreneurship. There is total blackout (no electricity) and cut-out (no accessfeeder roads), shortage of food, starvation and impoverishment mostly in the rural areas. Government policies have neglected those key areas. The farmers, fishermen and pastoralists work with crude implement, obsolete technologies and under very harsh environment (environmental constraints). There is the urgent need to identify the needs and gaps, interacting with stakeholders, knowing the constraints and the opportunities. This should be backed up with entrepreneurship development policies and programs that are practical, quick and proactive. For the thriving enterprises, entrepreneurship is concentrated in agriculture, imports and retail trade with very minimal value-added. Many factors work against entrepreneurship and poverty reduction in Nigeria. Firstly, Nigeria has the highest size of the informal sector and the largest number of disguise unemployment in Africa. Secondly, the level of corruption in the Nigerian has, in the past, stifled the efficacy of fiscal policy measures in the form of deficit budgeting as witnessed in derelict infrastructure all over the country. Thus, a special set of policy measures that will deal first with corruption is required in order to make public goods functional. White elephant projects covering huge amount in the public budget was no news. In Nigeria, generator dealers benefit from epileptic power supply, rice importers fight against "buy Nigeria", like wise importers of agricultural inputs fight against domestic manufacturing of these inputs. Thirdly, in Nigeria there is high deficiency or inefficiency in the use of capital. Funds should be made available to entrepreneurs. Young school leavers should be motivated to opt to be employers instead of looking for paid jobs. Fourthly, the challenges of globalization have put more pressure on unemployment in the present time, turning Nigeria into dumping ground for substandard products, including those that Nigeria would have been capable of producing. Nigeria entrepreneurs need special efforts and talents to be globally competitive. The top ten problems of entrepreneurship in Nigeria in a decreasing order are; management, access to finance, infrastructure, government policy inconsistencies and bureaucracy, environmental constraints, multiple taxes and levies, access to modern technology, unfair competition and corruption, marketing problems and lack of patronage for raw materials locally.

On the Plateau for instance, many women are operating commendable enterprises in poultry, fishery, vegetables and even retail businesses. The experiences of women entrepreneurs running their businesses include such problems as lack of enough capital, difficulties in transportation and marketing their products, perishability and lack of storage facilities and competing demand related to household chores. In spite of all these challenges, survey has shown that when properly enabled, women entrepreneurs perform as good, if not better than their male counterparts. Their rates of business survival are not more than men, but in terms of repayment rates for loans/credits, women in most cases did better than men. Women keep livestock as part of family assets and savings. In Plateau State and Kaduna State for instance, they are the backbone of family enterprises in poultry and fishery. In a related finding, there are links between trade liberalization, globalization and entrepreneurship in Nigeria. In the agricultural sector 
for instance, the sophistication of American and European agricultural technology has stifled innovation in Nigeria. The same is the case of manufacturing. If a Nigerian farmer could produce tomato, wheat, corn or rice, it is quicker, easier and cheaper for American and European agribusinesses. The same analysis goes for consumer goods from China. Nigerian entrepreneurs only help to market or sell the products of the first world in processed form. Wealth is created for the innovator, but the retailer is impoverished, always struggling to make ends meet. In this way, Nigeria has been drawn into the global marketplace based on expensive consumerism, including those things that can be produced at home. Programs of liberalization have usually required parallel programs of political and economic repression. The solution lies in the retailer becoming an inventor/innovator of his own products through entrepreneurship, with stiff regulation of imports and protection of domestic infant industries. In this way, China became the author of her own rapid economic transformation and poverty reduction. Nigeria should exercise no delay in creating science and technology parks, without any further hesitation. These will encourage domestic-technology clusters as it is done in the United States, United Kingdom, France, Canada, Germany, Japan, China, Australia, Israel, Brazil, and India etc. A science park is not only an innovative centre for entrepreneurship, but also a high revenue yielding venture. Nigeria with her huge population if adequately trained, can rapidly transform the economy, especially the industrial sector through innovative ventures. Revenues from science and technology parks can be much higher than that from oil, used in the execution of capital projects to multiply employment and reduce poverty. Stanford University Science Park, for instance, gave birth to what is today called "Silicon Valley" or Internet Valley with such end products as Intel, Yahoo, etc. This also applies to Massachusetts Institutes of Technology, (MIT) Science Park in Boston Mass, USA. For Europe and Asia, the establishment of science parks for some time now has made the world to realize that the best way to exploit speedily what the knowledge economy offers is to create the right environment for innovation to thrive,(Esping, 2003; Hoods et al., 2005). The number of new high-tech businesses, employment, and sales revenue from hightech products are dependent on science and technology parks cluster in developed and fast developing economies. In China for instance, one science park realized $\$ 25.92$ billion revenue in 2001,9000 high-tech businesses were in operation in the cluster, and a large number of 360,000 people were employed. The same multiplier effect holds for Taiwan, the United Kingdom, United States of America and South Korea. Nigeria should learn a lesson from a country like Japan, who does not have huge natural resources such as oil, but their economy thrives on innovation and entrepreneurship. The products are there to show for it;
Yamaha, Honda, Toyota, Toshiba etc.

In our analysis, SMEs have not contributed significantly to employment generation, especially in the Northern parts of Nigeria. The reasons for the poor performance of these enterprises include frequent religious, ethnic, and political crisis often witnessed in this region, thus making the environment not very conducive for business. Other constraints to Small and Medium Scale enterprises are infrastructure deficits, inadequate credit facilities from the banks and high cost of transaction/production. Also, there is lack of value-addition and absence of proper channels to market the products of those engaged in agriculture. These are the major causes of poverty and unemployment. . Better access to markets increases the value-added of farm products, enhances rural incomes and reduces income disparity between the rural and urban areas. This will promote incentives for peasants; make farming attractive and leading to increased agricultural productivity. It will also reduce labor mobility from rural to urban areas. Presently, the rural residents have very limited income opportunities; farmers do not have reasonable income from off-farm activities. Due to constrain in land conditions, electricity, and production technologies, even income from farming has been limited. Value-added production chains and improvement in infrastructure and technologies are needed in order to create the off-farm employment in the rural areas. In this way, unemployed and underemployed labor can be transferred from agricultural to non-agricultural sectors within the same locality.

There are instances where the elite class sometimes catches and traps all resources and benefits meant for the poorer people. Examples of such benefits include bank credit and marketing cooperatives, government, NGOs and private sector programs. A case was reported by slum residents in Jos, where a particular PHCN engineer diverted a rural transformer that was meant to generate electricity for rural populace to his private, fenced compound. There are also similar cases where subsidized tractors, fertilizers, irrigation projects disappear from the grasp of the absolute poor who were the target group for operation feed the nation or the green revolution. Land ownership is mostly appropriated and restricted to those with material resources and political power. Land grabbing therefore becomes a major barrier to profitable agricultural entrepreneurship. The economic dividends of democracy are yet to properly trickle down at the grassroots level where the core poor reside. The rural poor in Nigeria faces a complex, diverse and localspecific realities which policy makers that dwell in the cities (in air-conditioned offices) have failed to properly understand. Poverty in the rural areas has been the major cause of rural-urban migration. The level of development therefore is bound to be low since most of those who are supposed to contribute to rural development are forced by poverty to move to the cities. There are those, whose conditions are worst, they cannot 
afford to migrate, they just wait to die in their condition, while majority of those who moved without any acquired skills constitute urban nuisance. Poverty reduction policies in Africa did not achieve the objectives, as in Asia and Latin America, due to political instability, distorted government policies and the neglect of social and physical infrastructure, especially in the rural areas.

\section{Recommendations}

a. Government should sponsor industrial research, and produce business plans and feasibility studies including industry opportunity studies in Nigeria. Frequent workshops, seminars, conferences on entrepreneurship, should be organized by government, NGOs, financial, business, social and education institutions. Entrepreneurship ideas must be tendered like a garden in order to flourish. It is high time Nigerian youths started thinking and projecting themselves as employers of labor, as company-owning entrepreneurs and industrialists, not as helpless dependants. They should practice savings and investment of time, energy and capital. SMEs should learn to do budgeting, costing and strict financial control.

We recommend entrepreneurship education. Entrepreneurship training assists youths to develop positive attitudes, innovation and skills for self-reliance, rather than depending on the government for employment. The training that will produce graduates with self-confidence, and capacities for self-reliance, and the thought to discover new ideas, opportunities, and acquire information leading to economic and social development. Most importantly, entrepreneurship training should be opened to all and not exclusively for students in formal education or a certain sex or age group. Different aspects of entrepreneurship education should be offered at all levels of schooling; from primary, secondary schools through university and graduate programs. In this way, the skills and knowledge for business start- ups are learned, practiced and developed. Public and private schools should work closely (collaborates) with willing industries and companies to establish curriculum and programs to meet the skills requirements and labor market demands.

Government at federal, state and local levels should fine-tune the business environment and industrial policies in favor of entrepreneurship, especially small and medium scale enterprises.

The SMEs industry is seen as a key to Nigeria's growth, employment creation and poverty alleviation. SMEs bring about redistribution of income, wealth creation, economic self-reliance, entrepreneurial development, savings, investments and employment. There is need to improve the infrastructure of financial markets, especially of the credits system, and establish laws and regulations for financing SMEs. Making policies supportive of rural SMEs will be a good incentive. There is need to encourage the development of informal financial institutions that are particularly useful to SMEs in rural areas. This should help to reduce corrupt practices and information asymmetry between them and their clients. Information asymmetry entails moral hazard and adverse selection problems and increasing the risk of default on loans.

Some rapid developing countries like China, Indonesia and South Korea acquire technology transfer by imitation. Their governments put in place the necessary infrastructure, including science and industrial parks as incubation centers. This formula has afforded them a high rate of poverty reduction. Poverty motivates the rural poor to learn faster given the negative multiplier effects of poverty.

Nigeria must make concerted efforts to change the structure of the economy from being an import-dependent economy to export-oriented economy. Our industriesparticularly manufacturing must grow rapidly in response to the fast growing international trade. The development of an economy is determined by the competitiveness of its products in the domestic and international markets. Nigeria has scarcity of capital and abundance of labour. In order to achieve these, Nigeria must first choose industries according to her comparative advantage;laborintensive industries which require cost-minimizing technology, promote made-in-Nigeria goods and services. Households' incentive to safe would be high, and investment capital can enjoy the highest possible rate of returns, as many jobs as possible is guaranteed. Knowledge and technology spill over strengthens entrepreneurship, and creates potential market penetration. Government industrial regulation can be a big push for entrepreneurship.

The importance of human capital development cannot be underestimated. This process makes education broadbased and functional, cross-institutional and crossdisciplinary. It helps for capacity building and knowledge transfer. Effective funding of research and human capital development has dual benefits; it produces products and people, innovations and innovators.

The provision of social overhead capital facilities constitutes the primary requirements for industrial development. The secondary roles of government, on the other hand are in the form of policies, laws and incentives created to boost industrial participation, production and sustainable development.

\section{Conclusion}

Nigeria has a large economy and it is wealth-endowed. It has dynamic and resourceful population. Nigeria has entrepreneurship opportunities in agriculture, information technology, tourism, iron and steel, automobile, construction, craftsmanship, manufacturing, whole sale and retail trade, mining, finance, insurance, as well a 
renewable energy. However, efforts to decrease unemployment were hampered by over-dependence on crude oil, government revenue and expenditure. Increasing poverty and unemployment in Nigeria are the bane of policy failures. Government fiscal choices, action and inaction impinge on conditions of the poor. The role of entrepreneurship in reducing poverty is directly and indirectly by reducing unemployment and improving standard of living with income, new goods and services. Entrepreneurship will bring about the needed technical innovation and redistribution of employment opportunities. Fiscal priority can be placed on skills acquisition, rural development, agriculture, animal husbandry, community participation, forestry, community health, irrigation, rural education, infrastructure, land development and small scale business empowerment in rural areas. The poor and the unemployed deserve decent livelihoods. They need help to improve their productivity. They need to diversify their livelihoods in order to enhance and maintain the renewable resource base of the environment. They need entrepreneurship for sustainable development. . Every day in today's world, new business or company ideas are given birth. The inventors of the telephone, radio, airplane, computers, cars etc are long in history, but such innovations as Microsoft, face book, Apple, Blackberry, Samsung, Dell, IPod etc did not exist 30 years ago. Nigerians too can be in the list of global inventors. Regarding general macroeconomic and microeconomic policies, government has roles to encourage entrepreneurship, enhance propoor growth and poverty reduction through international trade, taxation, government expenditure, inflation control, infrastructure, education, health, viability of the legal system, and financial deepening. The positive effects of a well functioning legal and security systems, education, health, infrastructure and low inflation on entrepreneurship and poverty reduction cannot be overemphasized. Entrepreneurship and value-addition will halve poverty by helping to employ at least 50 percent of Nigeria's unemployed work force by 2026.

\section{REFERENCES}

Ahmad N, Hoffman A (2008). A Framework for Addressing and Measuring Entrepreneurship. OECD Statistics Working Papers. Paris, OECD Publishing. Available online:http//dx.doi.org/10.1787/243160627270. Accessed December, 20, 2015.

Aremu MA, Adeyemi SI (2011). Small and Medium Scale Enterprises as a Survival Strategy for Employment Generation in Nigeria. J. Sustain. Develop. 4(1): 200-206.

Bell M, Pavitt K (1993). Technological Accumulation and Industrial Growth: A Contrast. Oxford University Press.

Carree MA, Thurik AR (2003). The Impact of Entrepreneurship on Economic Growth. In Acs.Z.J. and Audretsch.D.B.(eds): Handbook of Entrepreneurship Research, Uk. Kluwer Academic Publishers, pp557-596.

Cemal Z, Busra M, Songul Z (2012). The impact of Corporate Entrepreneurship on Organizational Citizenship Behavior and Organizational Commitment: Evidence from Turkey SMEs. Eur. J. Innov. Manage. 17(2): 166-182.
Daniela S, Angela O (2012). Entrepreneurship and Sustainable Development in European Countries Before and During the International Crisis. Elsevier; Procedia-Social and Behavioral Sciences, 58: 889-898.

Eneji MA (2015). Applied Statistics and Research Methodology in Economics and the Social Sciences. Universal Academic Services, Lagos.

Eneji MA (2014). Entrepreneurship and Poverty Reduction in Nigeria. Universal Academic Services, Lagos.

Esping A (2005). The Three Worlds of Welfare Capitalism. Beijing Press.

Gao Q, Zhuang H (2011). Analysis of Innovative Capability of Agricultural Hi-Technology Industries in China. J. Innov. Manage. Pol. Pract. 13(3): 278-290.

Gries T, Naude' W (2008). Entrepreneurship and Structural Economic Transformation . UNU-WILDER Research Paper, No. 2008/62. United Nations University. World Institute for Development Economics Research.

Hoffman M (2008). Entrepreneurship, Creativity and Economic Development. Englewood Cliffs. NJ. Prentice Hall.

Hood SH, Hopson R, Frierson H (2005). The Role of Culture and Cultural Context in Evaluation. A Mandate for Inclusion, Theory and Practice. Greenwich.C.T.

Kabiru I, Dairo A (2000). The Implications of Vocational and Technical Education for National Growth and Development in the 21st Century. J. Women. Coll. Educ. 4: 20-28.

Kirzner IM (1998). How Markets Work: Disequilibrium Entrepreneurship and Discovery. Occassional Papers, Sydney Center for Independent Studies.

Lu D (1994). Entrepreneurship in Suppressed Markets: Private Sector Experience in China. New York, Garland Publishing.

Lv X, Cai G (2005). The Contribution of Small and Medium Scale Enterprises to Regional Economic Growth. Commer. Time, 30(9): 8999.

Mafuyal BH (2013). Making Research Innovation Count for Development. Carnegie Partnership, Jos.

Mailafia DI (2016). The Structural Dimensions of Unemployment, Associated Factors and Policies for Sustainable Development. Inaugural Lecture, University of Jos.

Malton PJ (1978). Income Distribution and Patterns of Expenditure, Savings and Credits Among Farmers in Northern Nigeria. J. Agric. Econ. 2(96): 82-93.

Naude' W (2010). Entrepreneurship, Developing Countries and Development Economics: New Approaches and Insights. J. Small Bus. Econ. 34(1): 1-12.

Naughton BJ (2007). The Chinese Economy: Transition and Growth. Cambridge, Management Institute of Technology(MIT) Press.

Ndebbio JEU (1984). Technological Transfer and the Growth Process in Less Developed Countries(LDCs). J. Intl. Foundation. Develop. Altern. (IFDA). Dossier 41, Switzerland 9(3): 106-120

Nihan Y, Olcay BA (2012). Entrepreneurship Intentions of Public Universities in Turkey: Going Beyond Education and Research. Elsevier; Procedia-Social and Behavioral Sciences, 58: 953-963.

Onugu BAN (2005). Small and Medium Scale Enterprises in Nigeria: Problems and Prospects. St Clement University, Lagos.

Pickle HB, Sao RLA (1976). Business Management. Santa Babara. John Wiley and Sons.

Ronstadt ER (1984). Entrepreneurship: Text Cases and Notes. Dover M.A.pp28-39.

Schumpeter JA (1934). The Theory of Economic Development. Cambridge,M.A. Harvard University Press.

Seyfi T, Nurdan C, Serkan.D.(2012). Evaluating Entrepreneurship Intentions of Vocational High School Pupils Based on Self-Efficiency Concept. Elsevier; Procedia-Social and Behavioral Sciences, Vol.58; pp 934-943.

Sobel RS (2008). Testing Baumol. Institutional Quality and the Productivity of Entrepreneurship. J. Bus. Venturing. 23(4): 641-655.

Thompson A (2005). Entrepreneurship and Business Start-Ups, and Business Planning. Perth, Best Entrepreneurs. 